\title{
Perception of English vowel contrasts by Acehnese- Indonesian bilingual learners of English
}

\author{
Tanzir Masykar ${ }^{1,2,3}$, Roshidah Binti Hasan ${ }^{2 *}$, Stefanie Pillai ${ }^{2}$ \\ ${ }^{1}$ Indonesian Endowment Fund (LPDP), Gedung Danadyaksa Cikini, Menteng, Jakarta Pusat, \\ ${ }^{2}$ Faculty of Languages \& Linguistics, Universiti Malaya, 50603 Kuala Lumpur, Malaysia, \\ ${ }^{3}$ DII Pondasi Beton dan Pengaspalan Jalan, Akademi Komunitas Negeri Aceh Barat, Ujong Tanoh Darat, Aceh \\ Barat, Indonesia 23681
}

\begin{abstract}
Previous studies have reported that second language (L2) learners filter non-native L2 sounds through their existing native or first language (L1) sounds when learning L2 sounds. The degree of similarity between L1 and L2 sounds can predict the ease of acquisition of non-native L2 sounds. In the context of English language learning in Indonesia, most learners are likely to speak two languages before they learn English at school; Acehnese is not without any exception. As a result, they have larger phonemic inventories to rely on when learning English sounds. This study seeks to investigate how Acehnese-Indonesian bilinguals perceive five sets of vowel contrast in English (i.e., /I/ - /i:/, /æ/ - / / /, / / / - /a:/, / / - /u:/, and /a:/ - /o:/). A special focus is given to their perception of English vowel contrasts that are new, similar, and identical to Acehnese and Indonesian vowels. A group of 31 high school students $(N=31)$ from an Islamic boarding school in Aceh participated in this study. An AX test comprising repetition and minimal pairs of English vowel contrasts in CVC word contexts was randomly presented to the students. The data were analysed by comparing the means of each vowel pair followed by a general linear model statistical analysis and interpreted based on speech perception and production models. The findings indicate that the Acehnese-Indonesian bilinguals discriminate the vowel pairs /æ/ - /3:/ and /a:/ - /o:/ better than the /I/ - /i:/, / / - /a:/ and /a:/ - /o:/ pairs. The vowel pairs in which both vowels are novel to Acehnese and Indonesian were moderately discriminated compared to the pairs in which one vowel is similar in both Acehnese and Indonesian. It can be said that students perceived pairs with one vowel similar to AcehneseIndonesian better than pairs with both vowels or one vowel novel in Acehnese and Indonesian. The findings reported in the paper are expected to inform pedagogic practices, particularly in the development of materials for the teaching of English pronunciation. English teachers in Aceh may incorporate Acehnese words that have similar sounds to English while emphasizing the novel sounds which are absent from the Acehnese vowel system.
\end{abstract}

Keywords: Acehnese-Indonesian bilinguals; perception of English vowel contrasts; phonemic contrast

$\begin{array}{lcc}\begin{array}{c}\text { First Received: } \\ \text { 10 June 2021 }\end{array} & \text { Revised: } & \text { Accepted: } \\ \text { Final Proof Received: } & \text { 5 January 2022 } & \text { 20 January 2022 } \\ \text { 27 January 2022 } & & \text { Published: } \\ \text { 31 January 2022 }\end{array}$

\section{INTRODUCTION}

L1 experience might impede the acquisition of nonnative phonemes if either one or both vowels in L2 vowel system are realized differently or are absent in the learner's L1 (Best, 1994a; Flege, 1995). When learning English vowels, Indonesian students may filter the vowels through their L1 vowel system. English vowels are different to Indonesian in terms

\footnotetext{
*Corresponding Author

Email: roshidah@um.edu.my
} 
of their quality and length (Deterding, 1997), while Indonesian and Acehnese vowels are different only in terms of quality as the differences in the length of a vowel in these languages do not distinguish one vowel from another (Pillai \& Yusuf, 2012). Some English vowels, however, are absent from the Indonesian and Acehnese vowel system such as /æ/, $/ \mathrm{I} /, / \mho /, / \mathrm{a}: /$ and $/ 3 \%$. Some are identical, such as $/ \mathrm{N} /$ and $/ \varepsilon /$, while others are similar but produced with a shorter duration such as /i:/, /u:/, and / $: /$. As far as the features of English vowels are concerned, Acehnese-Indonesian bilinguals may face difficulties discriminating these vowels if they fail to perceive them differently. Previous studies indicate that Acehnese speakers tend not to contrast typical English vowel pairs when one of the vowels is absent in their vowel system. Fata et al. (2017) found that Acehnese learners of English tend not to contrast English vowel pairs, such as /I/ and /i:/, /e/ and $/ æ /, / \mathrm{u} /$ and $/ \mho /$, and $/ \mathrm{a}: /$ and $/ \mathrm{\jmath} /$. In terms of perception, Perwitasari (2018), working with Javanese and Sundanese learners of English, reported that they had difficulties perceiving English vowels that were new to their L1 system. It was found that they have higher error rates perceiving the English vowels /I/, / /, / :/, /a:/, /3:/, and /æ/. It was also reported that Indonesian learners of English with Indonesian, Javanese, Sundanese, and Sulawesi as their respective first languages had difficulties discriminating English vowels in which one vowel in the pair is new to their vowel system such as /I/ - /i:/ /a:/ - /o:/ and / $/$ / - /a/ (Perwitasari, 2013).

Unlike Indonesian, Javanese, and Sundanese, the Acehnese language has a bigger vowel inventory and has sounds that do not exist in Indonesian, Javanese, and Sundanese. Acehnese vowels, such as $/ \Lambda /, / \varepsilon /$, and $/ \mathrm{w} /$, are absent in Indonesian (Soderberg \& Oslon, 2008; Zanten \& Heuven, 1984) as well as in Javanese and Sundanese (Perwitasari, 2019). In addition, there are some Acehnese vowels that are similar to English, such as $/ \Lambda /, / \supset /$, and $/ \varepsilon /$. While Acehnese $/ \Lambda /$ and $/ \varepsilon /$ are produced in a similar manner to English $/ \Lambda /$ and $/ \varepsilon /$, the vowel $/ \supset /$ in Acehnese is likely to be produced with a relatively shorter duration than English / :/.

Iverson and Evans (2007) argue that speakers with larger phonemic inventories may be able to make use of their existing vowels and perceive nonnative vowels better than speakers with smaller phonemic inventories. This is based on the findings from the perception of the English vowels by German, Norwegian, French, and Spanish speakers. They found that German and Norwegian speakers who have larger vowel systems were able to perceive English vowels better than Spanish and French speakers who have smaller vowel systems. Regarding the phonemic inventories, however, Elvin et al. (2014) found that size was not a good predictor for a more accurate perception of vowels. For instance, when discriminating non-native sounds of Brazilian Portuguese, Australian speakers were able to outperform the Iberian Spanish speakers, although Spanish has a larger vowel inventory. Confirming this finding, Alispahic et al. (2017) suggest that L1-L2 acoustic similarity better predict the ease of non-native vowel perception. Thus, since Acehnese has a larger vowel size and has vowels that are similar to English, these may help them acquire these English vowels. In relation to this, Acehnese Indonesian bilinguals are expected to perform better at discriminating English vowel pairs in which one or both vowels are present in their vowel inventories.

In relation to the L1-L2 similarities, at least three models have been proposed to explain the relationship. The first is the Speech Learning Model (SLM), which posits that if two similar phonemes between L1 and L2 are not distinguished, a perceptual association between the sounds may be created and it obstructs the construction of new phonemic categories in the L2 (Flege, 1995). The second model, the Perceptual Assimilation Model (PAM), further specifies that the ease of perception between a native and target sound can be predicted by the degree of similarity between two sounds (Best, 1995). The third model, Second Language Linguistic Perception (L2LP) model (Escudero, 2005), suggests that a direct link between perception and production exists. In this model, Escudero (2005) posits that comparisons of acoustic properties between L1 and L2 define listeners' ability to map and discriminate sounds that are not familiar to them. These models are plausible as it has been found that adult second language learners tend to use their L1 to filter L2 speech (Bongaerts et al., 1997; Escudero, 2005). The fact that they already have a particular phonemic inventory in their native language may encourage them to assimilate certain L2 sounds into their existing L1 sounds (Rallo Fabra, 2005; Rallo Fabra \& Romero 2012).

Even though studies on speech perception of English learners in English as a Foreign Language (EFL) settings have been on the rise in the last decade (e.g., Alispahic et al., 2017; Evans \& Alshangiti, 2018), studies on bilingual speakers of Southeast Asian languages, especially in the Indonesian context, are scarce (Fata et al., 2017; Perwitasari, 2013; Perwitasari, 2018). Studies on the perception of English vowels by Indonesian learners were conducted by Perwitasari $(2013,2018)$ where the learners in these studies were Javanese, Sundanese, and monolingual Indonesian speakers. These languages have smaller vowel systems compared to Acehnese and have less similar vowels to English. As far as Acehnese speakers are concerned, studies like Fata et al. (2017) only focused on the production of sounds. Thus, a study on the perception of English vowel contrasts by 
Indonesian bilinguals whose local language has vowels similar to English would enable us to understand if their existing vowel systems help them discriminate English vowels. Further, this study can contribute to our understanding of the way multilingual speakers with larger vowel inventories acquire English sounds. Considering that Indonesian speakers may have different vowel inventories depending on the languages they speak; the results of the study could be used to develop English pronunciation course materials tailored specifically to Acehnese-Indonesian learners of English. Thus, our study aims to address such issues by focusing on Acehnese-Indonesian bilinguals' perception of English vowels. This study is also expected to contribute to the research on speech perception in terms of whether speakers with larger phonemic inventories and have more vowels in their language which are similar to the target language are able to make use of their existing vowels when discriminating non-native vowel contrasts (Elvin et al., 2014; Iverson \& Evans, 2007). The following research questions are used as a general guide for addressing the following issues.

1. To what extent do Acehnese-Indonesian bilinguals perceive vowel contrast in English?

2. To what extent do their existing vowel systems contribute to their perception of vowel contrast in English?

\section{Language Perception Models}

As mentioned in the previous section, there have been at least three theoretical models proposed to describe the perceptual pattern of speech sounds, SLM, PAM, and L2LP. The acquisition of nonnative vowels and consonants (e.g., English for Italian speakers) in natural linguistic contexts is explained in SLM (Flege, 1995, 1999, 2003). Flege (1995) further argued that in order to accurately reproduce an L2 sound, learners would require three competencies. These competencies are, first, the ability to correctly examine the properties of the L2 sound. The second is the ability to differentiate the properties of the sound within L2 and against L1. The third competency is the ability to reproduce the represented L2 sound by learning its motoric gesture required to produce the sounds. The perception process of L2 sounds is said to occur in the first and the second competence.

PAM focuses on the perceptual ability of learners to acquire novel speech sounds in a foreign setting (Best, 1994b; 1995; Best \& Tyler, 2007). In its initial proposal, PAM focused heavily on naïve (as opposed to expert) listeners, but this was later extended to accommodate experienced L2 learners as PAML2 (Best \& Tyler, 2007). PAML2 proposed that if two L2 contrasts are assimilated into two separate L1 sounds or only one of the L2 sounds is assimilated into a single L1 sound, discrimination of the contrasts is predicted to be easier.
The L2LP model is specifically aimed at explaining the entire process of L2 acquisition. This model explains the L2 acquisition process from its initial state in which learners have to rely on their L1 to the development stage when they start to establish a separate system for L1 and L2 (Escudero et al., 2014). Escudero (2005) also proposed an optimal hypothesis in that the perception of L2 sounds depends on how the sounds are produced by the speakers in the L2 environment. Learners could become optimal listeners of that L2 sound if they are able to eventually discern its difference from the closest sound. Optimal listeners are usually achieved by advanced L2 learners who have received extensive input of L2 sounds. All of these three perception models hypothesize that the degree of similarity between the L1 and L2 sounds contributes to the perception of L2 sounds (Alispahic et al., 2017; Escudero et al., 2014; Escudero \& Williams, 2011).

\section{A Comparison of Acehnese, Indonesian, and Standard American English Vowels}

Acehnese has 10 monophthong oral vowels (Asyik, 1987; Durie, 1985; Yusuf, 2013). The vowels are /a/, /i/, /u/, /e/, /o/, /ə/, /w/, / //, / /, and / $/ \varepsilon /$ (see Table 1). All Acehnese oral vowels are lax vowels, and thus, differ in terms of length from some English tense vowels. Duration is not a distinctive feature in Acehnese. The Acehnese vowels $/ \Lambda /$ and $/ \varepsilon /$ are identical to English $/ \Lambda /$ and $/ \varepsilon /$ while Acehnese $/ \mathrm{i} /$, /u/ and /o/ are similar to English /i:/, /u:/ and / / :/ but are not lengthened in citation form.

Indonesian (BI) has a smaller vowel inventory compared to Acehnese (see Table 1). BI has six oral vowels /a/, /i/, /u/, /e/, /o/, and /ə/ (Soderberg \& Olson, 2008; Zanten, 1986), all of which are lax vowels. Based on Table 1, it is apparent that all Indonesian vowels exist in Acehnese. However, there are only two vowels in Indonesian which are similar to English, /i/ and / $\mathrm{u} /$ (also exists in Acehnese), both of which are shorter than English /i:/ and /u:/.

Standard American English has a total of 10 monophthongs /æ/, /I/, / /, /N/, /e/, /i:/ /u:/ /a:/ /o:/ and $/ 3 /$ (Ladefoged \& Johnson, 2014). English vowels differ from Acehnese and Indonesian both in quality and length. Four English vowels are long vowels, /i:/ /u:/ /a:/ /o:/ while the rest are shorter. Table 1 shows the vowel inventories of Acehnese, Indonesian, and American English.

Escudero (2005) suggested that the L1-L2 comparison of vowel inventories could predict the ease of the acquisition of the L2 vowels. Similarly, Best and Tyler (2007) also argued that listeners' relative ease and difficulty in perceiving non-native sounds could be predicted by comparing the phonetic similarities between L1 and L2. 
Table 1

Vowel Chart Comparison Across Acehnese (Asyik, 1987), Indonesian (Zanten, 1986), and American English (Ladefoged \& Johnson, 2014)

\begin{tabular}{|c|c|c|}
\hline English & Acehnese & Indonesian \\
\hline /i:/ & /i/ & /i/ \\
\hline$/ \mathrm{I} /$ & /e/ & /e/ \\
\hline /e/ & $|\varepsilon|$ & $/ \mathrm{a} /$ \\
\hline /æ/ & $/ \mathrm{w} /$ & /a/ \\
\hline$/ \Lambda /$ & $/ 2 /$ & $/ \mathrm{u} /$ \\
\hline /a:/ & $/ \Lambda /$ & $/ \mathrm{o} /$ \\
\hline $10: 1$ & /a/ & \\
\hline$/ v /$ & $/ \mathrm{u} /$ & \\
\hline $\mid 3 /$ & $/ \mathrm{o} /$ & \\
\hline /u:/ & $/ 2 /$ & \\
\hline
\end{tabular}

In determining the similarity, Flege (1987) coined the terms 'identical', 'similar', and 'new' (p. 48) to classify the L1/L2 phonemic comparisons. The terms can be classified by looking at three characteristics: (1) the IPA symbol L1 and L2 used to represent its sounds, (2) the difference in acoustic features of sounds in both languages, (3) the difference in the perception of the two languages. 'Identical' in Flege's term is then defined as sounds that have the same IPA symbols in both languages and have comparable acoustic features, while 'similar' is a term referring to sounds 'that differ systematically from an easily identifiable counterpart in LI' (Flege, 1987, p. 48). 'New' L2 sounds are those that do not occur in the L1. The English vowels /I/, / /, /æ/, and /a:/ do not have comparable sounds in Indonesian (Karlina et al., 2020) and Acehnese, and are thus, classified as 'new.'

By comparing phonetic similarity across three languages, we can classify which English vowels are considered similar, new, or identical phonemes for Acehnese-Indonesia bilinguals. The comparison and classification of vowels in English, Indonesian and Acehnese can be seen in Table 2. Only two English vowel pairs contain a similar vowel to Indonesian, while there are two vowel pairs containing an identical vowel and three vowel pairs containing a similar vowel to Acehnese. The English vowels /i:/ and /u:/ have comparable sounds in both Acehnese and Indonesian and are different only in terms of length. The English vowels $/ \mathrm{N} /$ and $/ \%$ / have equal sounds in Acehnese. However, the former is identical, while the latter is similar in terms of length.

We then organized the vowel pairs into four categories as can be observed in Table 3. These are NNB (New-New to Acehnese-Indonesian) and SNA (Similar-New to Acehnese) which have three vowel pairs each, and SNB (Similar-New to AcehneseIndonesian) and INA (Identical-New to Acehnese) which have two vowel pairs each. Whenever applicable, each of the pairs study will be referred to as VP1, VP2, VP3, VP4, and VP5 respectively, where VP refers to vowel pair.
Table 2

Comparison of English Vowel Pairs (VP) to Acehnese and Indonesian Based on the Framework by Flege (1987)

\begin{tabular}{|c|c|c|c|}
\hline & $\begin{array}{l}\text { Identical- } \\
\text { New }\end{array}$ & $\begin{array}{l}\text { Similar- } \\
\text { New }\end{array}$ & New-New \\
\hline Indonesian & $\mathrm{X}$ & $\begin{array}{l}\mathrm{i}:-\mathrm{I}(\mathrm{VP} 2) \\
\mathrm{u}:-\mathrm{v}(\mathrm{VP} 3)\end{array}$ & $\begin{array}{c}\varepsilon-æ(V P 1) \\
\Lambda-a:(V P 4) \\
\text { ग: - a: } \\
\text { (VP5) }\end{array}$ \\
\hline Acehnese & $\begin{array}{l}\Lambda-a:(V P 4) \\
\varepsilon-æ(V P 1)\end{array}$ & $\begin{array}{c}\mathrm{i}: \text { - I (VP2) } \\
\mathrm{u}:-\mathrm{v} \text { (VP3) } \\
\text { o: - a: (VP5) }\end{array}$ & $\mathrm{X}$ \\
\hline
\end{tabular}

\section{Table 3.}

Classification of English Vowel Pairs by NNB (NewNew to Acehnese-Indonesian), SNA (Similar-New to Acehnese), SNB (Similar-New to AcehneseIndonesian), and INA (Identical-New to Acehnese)

\begin{tabular}{|c|c|}
\hline Category & Vowel Pairs \\
\hline \multirow[t]{3}{*}{ NNB } & $\varepsilon-\mathfrak{e}(\mathrm{VP} 1)$ \\
\hline & $\Lambda-\mathrm{a}:(\mathrm{VP} 4)$ \\
\hline & o: - a: (VP5) \\
\hline \multirow[t]{3}{*}{ SNA } & i: - I (VP2) \\
\hline & $\mathrm{u}:-$ - (VP3) \\
\hline & o: - a: (VP5) \\
\hline \multirow[t]{2}{*}{ SNB } & i: - I (VP2) \\
\hline & u: - v (VP3) \\
\hline \multirow[t]{2}{*}{ INA } & $\Lambda-\mathrm{a}:(\mathrm{VP} 4)$ \\
\hline & $\varepsilon-\mathfrak{x}(\mathrm{VP} 1)$ \\
\hline
\end{tabular}

\section{METHOD}

This study employed an AX test to ascertain the discrimination of speech sounds by the participants. It was conducted in an Islamic boarding high school in Banda Aceh, involving one American English speaker and 31 Acehnese-Indonesian bilingual learners of English as participants.

\section{Participants \\ American English Speakers}

A 26-year-old American speaker provided the stimuli for our recording to be used for the perception task. The speaker worked as an ESL teacher at the Language Center of Syiah Kuala University for one and half years on a teacher exchange program. He had been in Aceh for one year at the time of the recording and considered himself to be monolingual. He was born and raised in Oregon and went to college in Ohio. He described himself as having a Western American accent. Before distributing the perception task to the target participants, the American speaker was recorded reading a list of words containing the target vowel embedded between consonants, i.e., a consonant vowel consonant (CVC) context within a carrier sentence of "I say (target word) again". The speaker was recorded with a Zoom H5 recorder in a sound- 
attenuated room at the Language Centre of Syiah Kuala University. The recordings were sampled at $44.000 \mathrm{kHz}$.

\section{Acehnese-Indonesian Bilingual Learners of English}

The participants who took part in the current perception study were 31 second- and third-year students in an Islamic boarding high school in Banda Aceh. They were aged between 16 and 18 years old with an average age of 17 years old. The students comprised 15 females and 16 males. All participants did not have any speech or hearing problems.

The participants were purposively selected based on their exposure to and use of English. At the school, students are required to speak English to their friends, teachers, and dormitory supervisors. In their first year, students are given a three-month period to code-switch between English, Acehnese, and Indonesian before required to use English daily throughout their study. At the boarding school, the students have an increased exposure to English, as they are only allowed to leave the school once every two weeks. This emphasis on English in an Islamic boarding school is not as surprising as it may seem. As Schneider (2003) explains, Islamic boarding schools in Indonesia are a sign that English penetrates beyond economics to "become a multicultural resource, dissociated from Western and English/American cultural contexts." (pp. 2829)

The students were in the second and third year of their high school at the time of the study and would have accumulated adequate peer exposure to English for about one to two and half years during their time at the school. The students in the current studies experienced both laboratory and immersion learning environments described by Jia et al. (2006) because they speak English regularly both during and outside school hours. The selection of students from boarding schools distinguishes the present study from previous ones, such as by Fata et al. (2017) who focused on non-boarding school students who learn English for about three to four hours per week during school hours. In order to ensure that the students had similar proficiency levels, they were selected based on their English examination scores in the final two semesters. Only students with an English score of at least 70 percent in the last two semesters were selected as participants. Based on their scores, the students can be considered to be at an intermediate level of English proficiency.

Prior to the selection, we distributed questionnaires to confirm that the students met the criteria of being bilingual in Indonesian and Acehnese. Since Acehnese is reported to have a wide variety of dialects (Asyik, 1987), only students from one regional dialect were selected. This was done to control the vowel inventory, which might be slightly different across Acehnese dialects. Since most students at the school are from the western part of Aceh, only those who spoke the west Acehnese dialect as their L1 participated in the study. All students reported using both Acehnese and Indonesian extensively at home, in their previous schools, or in the surrounding neighborhood back in their hometowns. We also made sure that the students only spoke Acehnese as their local language because people along the west coast of Aceh also speak Jamee, as reported by Yusuf et al. (2021).

\section{Instruments}

The target vowels were five typical English vowel pairs i.e., /I/ - /i:/, /æ/ - /e/, /N/ - /a:/, / / - /u:/, and /a:/ - /o:/. Each vowel was recorded in a CVC context word read by an American speaker of English (see Table 4). Each vowel was then extracted and sequenced into targeted pairs in a continuum with an interstimulus interval (ISI) of $700 \mathrm{~ms}$ and inter-trial interval (ITI) of $2000 \mathrm{~ms}$. Højen and Flege (2006) suggested that if the ISI between discriminated items is too short, listeners might perceive the items as inaccurate and incomplete. This may lower their score for accuracy.

Table 4

English Vowel Pairs and Words Used in the Study

\begin{tabular}{lcc}
\hline & Vowel Pairs & Word Pairs \\
\hline VP1 & $\mathbf{I}-\mathbf{i}:$ & bit - beat \\
VP2 & $\mathfrak{a}-\varepsilon$ & bag - beg \\
VP3 & $\boldsymbol{\sigma}-\mathbf{u}:$ & foot - food \\
VP4 & $\mathbf{\Lambda}-\mathbf{a}:$ & bud - bard \\
VP5 & $\mathbf{a}:-\mathbf{s}:$ & pot - port \\
\hline
\end{tabular}

The study used an AX test format, where, the vowel pairs were arranged in four possible stimuli, $\mathrm{AA}, \mathrm{AB}, \mathrm{BB}$, and BA. A was assigned one vowel such as /I/, and B was another vowel, such as /i:/, within the desired pairs. Each stimulus was then repeated five times, resulting in a total of 20 stimuli for each vowel pair and 100 stimuli for all the vowel pairs tested. The 20 stimuli of each vowel pair in each task type were randomized and divided into five blocks based on vowel pairs. Thus, VP1 is in the first block with 20 randomized stimuli followed by VP2, VP3, VP4, and VP5. The examples of randomized stimuli is presented in Table 5.

\section{Procedures}

The perception data were collected by asking the students to listen to instances of the vowel pair stimuli sequenced in the AX format, while doing the test. The test was conducted in a quiet multimedia computer room at the school. 
Table 5

AX Randomized Example for /I/ - /i:/ Block

\begin{tabular}{cclcc}
\hline Vowel Pair & Order & \multicolumn{1}{c}{ Stimuli } & Repetition & Total \\
\hline & AA & beat - beat & five rep. & \\
I - i: & AB & beat - bit & five rep. & \multirow{2}{*}{20} \\
$($ VP1 $)$ & BA & bit - beat & five rep. & \\
& BB & bit - bit & five rep. & \\
\hline
\end{tabular}

Prior to the test, consent forms were distributed, and the purpose of the test was explained to the participants. In addition, the school headmaster and head of dormitory supervisors provided permission to carry out the study prior to the test. A permit letter was also obtained from the regional office of the Ministry of Education, Indonesia, to carry out the perception test at the school. In the AX test, students were given papers to mark in column as 'same' or 'different' based on the stimuli they heard. The first stimulus block was played to familiarize students with the test, after which the students continued the rest of the block until the end of the test.

\section{Data Analysis}

The answer sheets were then tabulated into an Excel sheet. A score of '1' was given for the correct answer and ' 0 ' for the incorrect answer. The score was given based on the stimuli given. If students answered 'same' for the stimuli containing the same vowel pairs, they would get ' 1 ' for that stimulus, and if they answered otherwise, they would get ' 0 '. The mean percentage score of each vowel pair was calculated to determine their perception accuracy. To answer research question 1 (RQ1) (To what extent do Acehnese-Indonesian bilinguals perceive vowel contrast in English?), we compared the mean perception of accuracy across the five vowel pairs using the one-way ANOVA test. An additional post hoc Tukey HSD test was conducted to see which vowel pairs are significant against another. For research question 2 (RQ2) (To what extent do their existing vowel systems contribute to their perception of vowel contrast in English?), we classified the results from research question one into identical, similar, and new categories and interpreted the data accordingly. The data were interpreted through three prominent speech learning models, SLM (Flege, 1995, 1999, 2003), PAM (Best, 1994b; 1995; Best \& Tyler, 2007), and L2LP (Escudero, 2005; Escudero et al., 2014; Escudero \& Williams, 2011).

\section{FINDINGS}

To What Extent Do Acehnese-Indonesian Bilinguals Perceive Vowel Contrast in English?

Figure 1 shows the mean percentage of perception accuracy across five English vowel pairs /I/ - /i:/, /æ/ - /3:/, / / - /u:/, / / - /a:/, and /a:/ - /o:/ by AcehneseIndonesian bilingual learners of English. The lowest percentage of accuracy was obtained for /æ/ - /3:/ while the highest was observed in $/ \Lambda /-/ a: /$ Two vowel pairs, /æ/ - /3:/ and /a:/ - / $: /$ sit at the bottom of the curve below 80 while the rest vowel pairs are above 95

\section{Figure 1}

Mean Percentage of Each Vowel Pair in AX Test

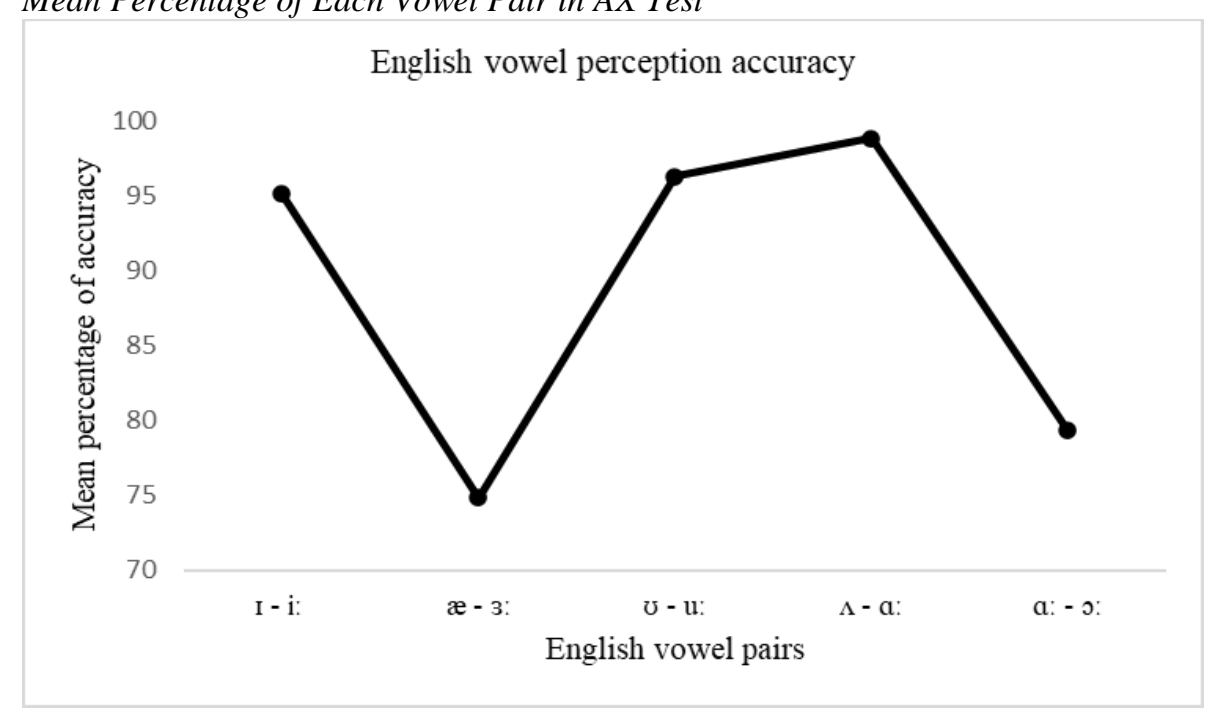

The mean difference in percentage of accuracy between /æ/ - /3:/ and /a:/ - / :/ was 5 points at 75 and 80 respectively (see Table 6).. While the mean accuracy for $/ \Lambda /$ - /a:/ almost reached a perfect score at 99, the values for vowel pairs / / / / u:/ and /I/ - /i:/ were slightly lower at 95 and 96 respectively. The 
mean difference between the vowel pairs with lower accuracy and higher accuracy were quite high at 15 points.

The distribution of mean and standard deviation for each vowel pair is shown in Table 6 . All the vowel pairs displayed greater variation except for VP4. The participants' perception accuracy had the greatest variation for VP5 and VP1 which indicates that accuracy distribution is not uniform for this pair.

Table 6

Mean Score and Standard Deviation for Each English Vowel Pair

\begin{tabular}{|c|c|c|c|}
\hline & Vowel Pairs & Mean & SD \\
\hline VP1 & I - i: & 95.16 & 9.35 \\
\hline VP2 & $æ-3:$ & 74.84 & 8.80 \\
\hline VP3 & $v-u:$ & 96.29 & 7.07 \\
\hline VP4 & $\Lambda-a:$ & 98.87 & 2.80 \\
\hline VP5 & $a:-0:$ & 79.35 & 10.06 \\
\hline
\end{tabular}

The findings indicate that the participants' perception is priming to the 'new' vowel pairs (VP2) that are non-existent in both Acehnese and Indonesian and the pair (VP5) in which one vowel exists only in Acehnese. The perception accuracy was higher for the vowel pairs (VP1 \& VP3) in which one of them is similar in both Acehnese and Indonesian, i.e., /i:/ and /u:/, and highest for the vowel pairs with one vowel identical only to Acehnese (VP4).

\section{Figure 2}

Mean Percentage of Accuracy based on NNB (New-New to Acehnese-Indonesian), SNA (Similar-New to Acehnese), SNB (Similar-New to Acehnese-Indonesian), and INA (Identical-New to Acehnese) Categories

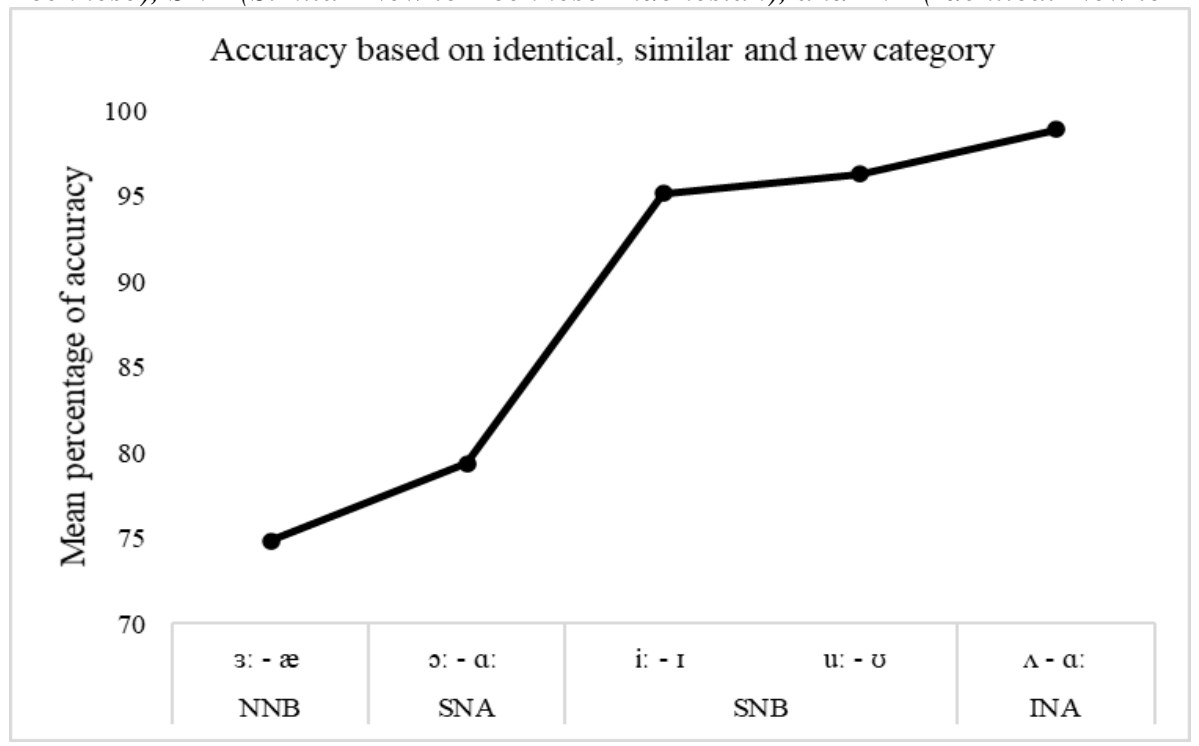

\section{DISCUSSION}

Perception of Acehnese-Indonesian bilinguals towards vowel contrast in English

In RQ1, we sought to describe how AcehneseIndonesian bilingual learners of English perceive
To What Extent Do Their Existing Vowel Systems Contribute to Their Perception of Vowel Contrast in English?

In order to see how the degree of similarity between L1 and L2 contributes to the perception accuracy of English vowel pairs, we plotted the data from Figure 1 into similarity categories we presented in Table 3 . Figure 2 shows that the participants scored the lowest accuracy for the English vowel pairs that do not exist in Acehnese and Indonesian (NNB) and this is followed by the English vowel pairs in which one vowel is similar to Acehnese while the other is new to Acehnese and Indonesian (SNA). The vowel pairs in which one vowel is identical to Acehnese and the other is new to Acehnese and Indonesian (INA) $\mathrm{s}$ reached the highest accuracy at 99. The participants seem to consistently perceive English vowel pairs in which one of the pairs exists in Acehnese and Indonesian at a similar level, 95 and 96, respectively. A Tukey HSD post hoc (at a confidence level of 95\%) indicated that the perception accuracy of NNB and SNA vowel pairs are in the same category $(\mathrm{p}=0.182)$ while the SNB and INA pairs were in another category $(\mathrm{p}=0.369)$. This indicates that the participants performed equally between NNB and SNA vowel pairs and SNB and INA pairs. 
All of them can perceive the English vowel contrast at above chance level; beyond 50\% (Barrios et al., 2016) and $70 \%$ (Jia et al., 2006). It is found that some English vowel pairs were difficult to perceive while some others are easier. Our participants had lower perception accuracy for the English vowel pairs /æ/ - /3:/ and /a:/ - / :/ and higher perception accuracy for the vowel pairs /I/ - /i:/, / / - /u:/, and $/ \Lambda /$ - /a:/. Lower perception accuracy for the vowel /æ/ and /3:/ was also observed in Javanese and Sundanese speakers of English by Perwitasari (2018). Our study confirms that Indonesian speakers regardless of their first languages (e.g., Acehnese, Javanese, and Sundanese, and Indonesian) continue to experience difficulties in perceiving the /æ/ - /3:/. However, Perwitasari (2018) also found that Javanese and Sundanese speakers showed higher error rates when perceiving vowels $/ \mathrm{\Lambda} /$, /a:/, and $/ \mathrm{I} /$ which is not the case with Acehnese speakers. Javanese speakers even exhibit difficulties with another English vowel / $/$. The difference in the methodology used in the current study may have contributed to a different result, for example, Perwitasari (2018). In the current study, we used the AX test, which is commonly used in perception tests (Barrios et al., 2016; Mora, 2005), while Perwitasari (2018) conducted a mouse-tracking study. The fact that Acehnese speakers have a larger phonemic inventory compared to Javanese and Sundanese may also have contributed to the higher accuracy in most vowel contrast. The study by Iverson and Evans (2007) also confirmed our findings. In their study, Norwegian and German listeners (with larger L1 phonemic inventory) outperformed Italian and Spanish (with smaller L1 phonemic inventory) when identifying English vowels. Even though the current findings seem to negate the findings found by Alispahic et al. (2017) in which listeners with larger phonemic inventories fail to utilize their native vowels in discriminating novel vowel contrast, Alispahic et al. (2017) concluded that larger vowel inventory is not the sole predictor for the acquisition of novel vowel contrast. The closeness of the vowel properties in listeners' L1 to the target L2 plays a far more crucial role in determining the ease of discriminating vowel contrast. Acehnese and Indonesian bilinguals have not only large phonemic inventories but also have vowels that are identical to English $/ \Lambda /$ and similar to English / $/ /$ and they are absent in the Indonesian vowel system.

The higher error rates for the vowel contrast /a:/ - / $/ /$ in the current study are similar to the study by Fata et al. (2017). The Acehnese learners of English in their study also did not contrast the vowel pairs /a:/ - /o:/. However, this conclusion needs to be treated cautiously since the Acehnese speakers in their study also did not contrast the /I/ - /i:/ and / $/$ / /u:/ pairs. Different proficiency levels of the participants in our study and that of Fata et al. (2017) may also explain the discrepancies in the current findings. However, it is important to highlight that their study focused on production while our study concentrated on perception. While the proficiency level of our participants is at an intermediate level, their study did not mention the proficiency level of their respondents. These factors could have resulted in different findings. However, Flege (1995) suggested that the state of phonemic perception is not constant but improved over the years as learners receive more input. They found that Japanese speakers living in the United States were eventually able to discriminate between the sound $/ \mathrm{r} /$ and $/ \mathrm{l} /$ after living there for two years. Learners also learn to pick up more cues to distinguish non-native vowel contrasts as they are exposed to more input from the target language. Length of exposure to L1 input was also reported to influence language acquisition (Jiat et al., 2006). The participants in the current study may have been at a certain level of their developmental stage of English vowel contrast acquisition and are at a different stage of language development from the Acehnese-Indonesian in Fata et al. (2017).

\section{The Contribution of Acehnese-Indonesian Bilinguals Existing Vowel Systems to the Perception of Vowel Contrast in English}

In RQ2, we aimed to find out how the similarity or difference between the existing AcehneseIndonesian vowels and English vowels contribute to their perception accuracy. By examining the similarity between native vowels (Acehnese and Indonesian) and non-native vowels (English), we can determine how the Acehnese-Indonesian bilinguals perceived vowel contrasts based on their proximity to properties in the native vowels (see Table 2 and Figure 2). The lowest percentage of perception accuracy was recorded for the pairs /æ/ /3:/ and /a:/ - /o:/. As mentioned previously, English $/ æ /$ and /3:/ vowels are both novel to Acehnese and Indonesian bilinguals since both vowels do not exist in the vowel inventories of these two languages. However, one of the vowels in the /a:/ - /o:/ vowel pair is present in Acehnese. The English tense / $/ \mathrm{s}$ is similar to Acehnese lax /o/, and thus, we would have anticipated that the participants would be able to recognize / $:$. While we predicted that /æ/ - /3:/ vowel pair would be difficult to be discriminated since they are new to Acehnese and Indonesian speaker, we did not expect the perception of the /a:/ - /o:/ vowel contrast to exhibit lower scores. The difficulty in perceiving the /æ/ - /3:/ contrast can be explained based on two possible factors. First, it can be explained by the L2LP model (Escudero, 2005), which states that L2 learners filter L2 sound through their L1, and whenever available, they will use any closest L1 sound when perceiving non-native sound. Since both English /æ/ and /3:/ vowels are novel in the Acehnese and Indonesian vowel systems, they do not have any L1 sound to compare with the two 
novel sounds. Thus, the two sounds are mapped into a single category and perceived as an instance of the same sound. Second, the results for the /a:/ - /o:/ pair can also be explained based on the optimal perception hypothesis (Escudero, 2005). The Acehnese-Indonesian bilinguals in our study may not have received enough optimal input to pick up the minimal difference properties between the two non-native sounds. During their high school, they lived in the dormitories, and the pronunciation input they obtained would have been from their friends who were also learning English or from their English teachers in the class, who were mainly Indonesians

The explanation for low perception accuracy for /a:/ - / $/$ :/ can be best explained from the SLM hypothesis by Flege (1995), which suggests that a new category cannot be established if the difference between L2 sound and the closest L1 sound is not well discerned. The Acehnese-Indonesian bilinguals in our study were unable to discern the difference between the new non-native sound /a:/ and the closest existing native sound $/ \mathrm{s} /$ which result in their poor perception between the new sound /a:/ and similar sound /5:/. PAM (Best, 1994b) and L2LP (Escudero, 2005) also predict that when non-native vowel contrast is mapped into the single native vowel, the vowels would be difficult to discriminate. This scenario is called the new scenario in L2LP or a single category in PAM. The new non-native English /a:/ and similar non-native English /o:/ may have been mapped into the native Acehnese lax vowel / $/$. Their failure to differentiate between the new-new sound /æ/ - /3:/ and new-similar sound /a:/ - /o:/ indicates that Acehnese-Indonesian bilinguals not only have a difficulty in perceiving totally new vowel contrast but also vowel contrasts in which one of the pairs contains sound similar only to Acehnese. An in-depth study for these particular vowel pairs on other Acehnese-Indonesian bilinguals needs to be done to confirm this assumption.

The next three vowel contrasts /I/ - /i:/, / / /u:/, and $/ \Lambda /-/ \mathrm{a}: /$ are different from the previous two pairs /æ/ - /3:/ and /a:/ - /o:/. Both English /i:/ and /u:/ have comparable sounds in both Acehnese and Indonesian /i/ and /u/. While the English /i:/ and /u:/ are tense vowels with longer duration, AcehneseIndonesian /i/ and / $/ \mathrm{h}$ are lax vowels with shorter duration. Acehnese-Indonesian bilinguals participated in the study perceive the two pairs comparably well. They may have successfully used the cue from the target language in terms of duration coupled with the reuse of their existing vowel to discriminate between the two sounds. On the other hand, the English $/ \Lambda /$ has an identical sound in Acehnese $/ \Lambda /$ and was found to be the easiest to perceive, reaching almost a perfect level. However, the three-vowel contrasts are in the same homogenous subset and are perceived comparably well by Acehnese-Indonesian bilinguals. For these particular English vowel contrasts, the current participants have reached optimal listeners and can be said at the end state of their vowel acquisition (Escudero, 2005).

\section{CONCLUSION}

The study reported in this paper has presented the perception of English vowels by AcehneseIndonesian bilingual learners of English. Utilising language perception models as a general framework, we have identified how Acehnese-Indonesian bilinguals perceive vowel contrast in English as well as the contribution of their existing vowel systems to their perception of vowel contrast in English.

In terms of the perception of vowel contrasts, we addressed how Acehnese-Indonesian bilinguals perceive the contrast in five typical pairs of English vowels. On the one hand, we found that their perception varies across the five pairs with both the vowel contrast between /æ/ - /3:/ and /a:/ - / :/ were poorly perceived compared to the other three vowel contrasts. On the other hand, the participants found the pairs $/ \Lambda /-/ \mathrm{a}: /, / \mathrm{I} / \mathrm{-} / \mathrm{i}: /$, and $/ \mathrm{\mho} / \mathrm{-} / \mathrm{u}: /$ easier to perceive. This was particularly so for the $/ \Lambda /$ - /a:/ pair, indicating that they are at the end state of vowel acquisition for these vowel pairs.

Regarding the contribution of students' existing vowel systems to the perception of vowel contrast in English, we found that the perception accuracy of English vowel contrast is, to a certain extent, linked with the degree of similarity between native vowels and non-native vowels. The contrast in the pair /æ/ - /3:/, in which both vowels are not present in the Acehnese-Indonesian vowel system was difficult to discriminate; while the pair/ø/ - /u:/ and /I/ - /i:/, which contain one vowel similar to Acehnese and Indonesian, were perceived considerably well. The contrast between English vowel pair, / $/$ / - /a:/, which contains one vowel identical to Acehnese but not to Indonesian, was easily perceived. However, the AcehneseIndonesian bilinguals had difficulties discriminating the vowel pair /a:/ - /o:/, which contains one vowel only similar to Acehnese but not to Indonesian. It may be the case that they failed to optimally reuse the knowledge of their native vowel to perceive non-native English vowel contrast. In fact, their difficulty is in the homogenous subset of the novel non-native vowel pairs (/æ/ - /3:/).

The findings reported in the paper contribute to our understanding of the perception of English vowel contrast by Acehnese-Indonesian bilingual learners of English. It sheds light on which vowel contrasts are easier to discriminate and which are difficult. It also provides a glance at how the degree of similarity between Acehnese-Indonesian and English vowels can predict the relative degree of 
perception accuracy of non-native English vowel contrast.

The findings can also be used to inform pedagogic practices related to the teaching of English vowels. For instance, references to equivalent sounds in Acehnese words can be used for English words containing identical and similar sounds. For the identical pair $(/ \Lambda /-/ \mathrm{a}: /)$ in which $/ \Lambda /$ is identical to Acehnese while /a:/ is novel, teachers can mention that the $/ \Lambda$ / sound is produced similar to the vowel in Acehnese words, "pö /p $/$ [fly]" and "pöt /p $\Lambda$ t/ [pluck, pick]." They can highlight the fact that the vowel /a:/ does not exist in Acehnese vowel systems. For similar pairs (/a:/ - /o:/, /I/ - /i:/, / / /u:/), Acehnese words with similar vowels can be used for reference and additional emphasis on length can be made for / $/: /, / \mathrm{i} /$, and /u:/ vowels. The other three vowels, /a:/, /I/, and / / which are new to the Acehnese vowel system should be focused upon. Incorporating native language sounds for reference into pronunciation courses could make the learners aware of which English vowels are identical, similar, and new to the Acehnese vowel system.

\section{ACKNOWLEDGEMENTS}

This research was supported by Indonesian Endowment Fund (LPDP), Indonesian Ministry of Finance, through the LPDP Scholarship for the Doctor of Philosophy Programme at Universiti Malaya, Malaysia.

\section{REFERENCES}

Alispahic, S., Mulak, K. E., \& Escudero, P. (2017). Acoustic properties predict perception of unfamiliar Dutch vowels by adult Australian English and Peruvian Spanish listeners. Frontiers in Psychology, 8, 52. https://doi.org/10.3389/fpsyg.2017.00052

Asyik, A. G. (1987). A contextual grammar of Acehnese sentences [Unpublished doctoral thesis]. University of Michigan.

Barrios, S. L., Jiang, N., \& Idsardi, W. J. (2016). Similarity in L2 phonology: Evidence from L1 Spanish late-learners perception and lexical representation of English vowel contrasts. Second Language Research, 32(3), 367-395. https://doi.org/10.1177/0267658316630784

Best, C. T. (1994a). The emergence of nativelanguage phonological influences in infants: A perceptual assimilation model. In J. C. Goodman \& H. C. Nusbaum (Eds.), The development of speech perception: The transition from speech sounds to spoken words (pp. 167-224). MIT Press.

Best, C. T. (1994b). Learning to perceive the sound pattern of English. In L. P. Lipsitt \& RoveeCollier, C. K. (Eds.), Advances in infancy research, Vol. 9 (pp. 217-304). ABLEX

Publishing Corporation.

Best, C. T. (1995). A direct realist view of crosslanguage speech perception. In Strange, W. (Ed.), Speech perception and linguistic experience: Issues in cross-language research (pp. 171-206). York Press.

Best, C. T., \& Tyler, M. D. (2007). Non-native and second-language speech perception. In O.-S. Bohn \& M. J. Munro (Eds.), Language experience in second language Speech learning: In honor of James Emil Flege (pp. 13-34). John Benjamins Publishing.

Bongaerts, T., van Summeren, C., Planken, B., \& Schils, E. (1997). Age and ultimate attainment in the pronunciation of a foreignlanguage. Studies in Second Language Acquisition, 19(4), 447-465. https://doi.org/10.1017/S0272263197004026

Deterding, D. (1997). The formants of monophthong vowels in Standard Southern British English pronunciation. Journal of the International Phonetic Association, 27, 47-55. https://doi.org/10.1017/S0025100300005417

Durie, M. (1985). A grammar of Acehnese on the basis of a dialect of north Aceh. Foris Publications.

Elvin, J., Escudero, P., \& Vasiliev, P. (2014). Spanish is better than English for discriminating Portuguese vowels: acoustic similarity versus vowel inventory size. Frontiers in Psychology, 5, 1188. https://doi.org/10.3389/fpsyg.2014.01188

Escudero, P. (2005). Linguistic perception and second language acquisition: Explaining the attainment of optimal phonological categorization [Unpublished doctoral dissertation]. Utrecht University \& LOT.

Escudero, P., Sisinni, B., \& Grimaldi, M. (2014). The effect of vowel inventory and acoustic properties in Salento Italian learners of Southern British English vowels. The Journal of the Acoustical Society of America, 135, 1577-1584. https://doi.org/10.1121/1.4864477

Escudero, P., \& Williams, D. (2011). Perceptual assimilation of Dutch vowels by Peruvian Spanish listeners. The Journal of the Acoustical Society of America, 129, EL1-L7. https://doi.org/10.1121/1.3525042

Evans, B. G., \& Alshangiti, W. (2018). The perception and production of British English vowels and consonants by Arabic learners of English. Journal of Phonetics, 68, 15-31. https://doi.org/10.1016/j.wocn.2018.01.002

Fata, I. A., Fitrian, F., Mohammad, T., \& Yusuf, Y. Q. (2017). Acoustic analysis on English oral vowels produced by Acehnese speakers from Aceh Besar by using PRAAT software. Proceedings of the $7^{\text {th }}$ Annual International Conference (AIC) Syiah Kuala University and 
the $6^{\text {th }}$ International Conference on

Multidisciplinary Research (ICMR) in conjunction with the International Conference on Electrical Engineering and Informatics (ICELTICs) 2017 (pp. 591-596).

Flege, J. E. (1987). The production of "new" and "similar" phones in a foreign language: Evidence for the effect of equivalence classification. Journal of Phonetics, 15(1), 4765. https://doi.org/10.1016/S00954470(19)30537-6

Flege, J. E. (1995). Second language speech learning: Theory, findings, and problems. In W. Strange (Ed.), Speech perception and linguistic experience (pp. 233-277). York Press.

Flege, J. E. (1999). The relation between L2 production and perception. Proccedings of the 14th International Congress of Phonetic Sciences, 1273-1276.

https://www.internationalphoneticassociation.o rg/icphsproceedings/ICPhS1999/papers/p14_1273.pdf

Flege, J. E. (2003). Assessing constraints on secondlanguage segmental production and perception. In A. S. Meyer \& N. O. Schiller (Eds.), Phonetics and phonology in language comprehension and production: Differences and similarities (pp. 319-355). De Gruyter Mouton.

Højen, A., \& Flege, J. E. (2006). Early learners' discrimination of second-language vowels. The Journal of the Acoustical Society of America, 119(5), 3072-3084. http://dx.doi.org/10.1121/1.2184289

Iverson, P., \& Evans, B. G. (2007). Learning English vowels with different first-language vowel systems: Perception of formant targets, formant movement, and duration. The Journal of the Acoustical Society of America, 122(5), 2842-2854. https://doi.org/10.1121/1.2783198

Jia, G., Strange, W., Wu, Y., Collado, J., \& Guan, Q. (2006). Perception and production of English vowels by Mandarin speakers: Agerelated differences vary with amount of L2 exposure. The Journal of the Acoustical Society of America, 119, 1118-1130. https://doi.org/10.1121/1.2151806

Karlina, Y., Rahman, A., \& Chowdhury, R. (2020). Designing phonetic alphabet for Bahasa Indonesia (PABI) for the teaching of intelligible English pronunciation in Indonesia. Indonesian Journal of Applied Linguistics, 9(3), 724-732.

Ladefoged, P., \& Johnson, K. (2014). A course in phonetics $\left(7^{\text {th }}\right.$ ed.). Cengage Learning.
Mora, J. C. (2005). Lexical knowledge effects on the discrimination of non-native phonemic contrasts in words and nonwords by Spanish/Catalan bilingual learners of English. Proceedings of the ISCA Workshop on Plasticity in Speech Perception (pp. 43-46).

Perwitasari, A. (2013). Slips of the ears: Study on vowel perception in Indonesian learners of English. Jurnal Humaniora, 25(1), 103-110. https://doi.org/10.22146/jh.1816

Perwitasari, A. (2018). Perception of English vowels by Javanese and Sundanese speakers: A mouse-tracking study. Wacana, 19(1), 219234. http://dx.doi.org/10.17510/wacana.v19i1.607

Perwitasari, A. (2019). The acquisition of English vowels by Javanese and Sundanese native speakers [Unpublished doctoral dissertation, Leiden University].

Pillai, S., \& Yusuf, Y. Q. (2012). An instrumental analysis of Acehnese oral vowels. Language and Linguistics, 13, 1029-1050.

Rallo Fabra, L. (2005). Predicting ease of acquisition of L2 speech sounds. A perceived dissimilarity test. Vigo International Journal of Applied Linguistics, 2, 75-92.

Rallo Fabra, L., \& Romero, J. (2012). Native Catalan learners' perception and production of English vowels. Journal of Phonetics, 40(3), 491-508. https://doi.org/10.1016/j.wocn.2012.01.001

Soderberg, C., \& Olson, K. (2008). Indonesian. Journal of the International Phonetic Association, 38(2), 209-213. https://doi.org/10.1017/S0025100308003320

Schneider, E. W. (2003). The dynamics of New Englishes: From identity construction to dialect birth. Language, 79(2), 233-281. https://doi.org/10.1353/LAN.2003.0136

Yusuf, Q. (2013). Rejuvenating the agenda for early childhood in Acheh after the tsunami. Southeast Asia Early Childhood Journal, 2, 38-50.

Yusuf, Y. Q., Fata, I. A., \& Karwinda, S. (2021). Oral monophthong vowel qualities of the Jamee language in Aceh. Indonesian Journal of Applied Linguistics, 10(3), 794-803. https://doi.org/10.17509/ijal.v10i3.31767

Zanten, E. V. (1986). Allophonic variation in the production of Indonesian vowels. Perception, 142, 427-446.

Zanten, E. V., \& Heuven, V. J. v. (1984). The Indonesian vowels as pronounced and perceived by Toba Batak, Sundanese and Javanese speakers. Bijdragen tot de Taal, Land-en Volkenkunde, 140(4), 497-521. 